\title{
Using FITradeoff in a ranking problem for supplier selection under TBL performance evaluation: An application in the textile sector
}

\author{
Lorena Vieira Santos Rodrigues ${ }^{\mathrm{a}}$ (D), Ramon Swell Gomes Rodrigues Casado ${ }^{\mathrm{b}}$ (D), \\ Edinalva Nogueira de Carvalho (D), Maisa Mendonça Silva ${ }^{\mathrm{a}, \mathrm{b}}$ (D), Lúcio Camara e Silva ${ }^{\mathrm{a} *}$ \\ anniversidade Federal de Pernambuco, Centro Acadêmico do Agreste, Caruaru, PE, Brasil \\ bUniversidade Federal de Pernambuco, Centro de Desenvolvimento em Sistemas de Informação e Decisão, Recife, PE, Brasil \\ *lucio_camara@hotmail.com
}

\begin{abstract}
Paper aims: This paper proposes a multicriteria decision approach for supplier selection using a multicriteria method based on Flexible and Interactive Tradeoff (FITradeoff) elicitation process, within the ranking problematic perspective.

Originality: This paper develops a framework integrating the results of VFT (Value-Focused Thinking) method with the Triple Bottom line (TBL) dimension and the veto concept to improve the decision process within a multicriteria perspective.

Research method: This study provides a case study in a textile company in Campina Grande, northeast Brazil using data mainly from semi-structured interviews. It also employs quantitative techniques based on problem structuring methods and multicriteria decision making.

Main findings: The VFT helped in identifying criteria that are not yet explored by the company, and in structuring the decision problem of how incorporate and balance the TBL dimensions. The recommendation obtained by using the proposed multicriteria decision framework is different from the group of suppliers currently used by the company.

Implications for theory and practice: Clarify and identify different objectives and to specify the consequences of a decision problem, allowing the Decision Maker (DM) to obtain and prioritize an economic and sustainable solution for a given number of suppliers to be selected, saving his time and effort.
\end{abstract}

Keywords

Supplier Selection. FlTradeoff. Ranking problematic. Value Focused Thinking (VFT). Triple Bottom Line (TBL).

How to cite this article: Rodrigues, L. V. S., Casado, R. S. G. R., Carvalho, E. N., Silva, M.M., \& Camara e Silva, L. (2020). Using FITradeoff in a ranking problem for supplier selection under TBL performance evaluation: An application in the textile sector. Production, 30, e20190032. https://doi.org/10.1590/0103-6513.20190032.

Received: Apr. 15, 2019; Accepted: Jan. 30, 2020.

\section{Introduction}

According to (Segura \& Maroto, 2017), companies are not able to offer a sustainable and quality manufacturing without excellent raw materials. Thus, supplier selection and evaluation have received considerable attention (Hamdan \& Cheaitou, 2017) and are considered one of the critical factors that can affect final revenues (Chen $\&$ Zou, 2017), especially when companies are improving the quality and reducing cost (price) of their products (Wan et al., 2017). Thus, selecting appropriate suppliers and maintaining good relationships with them are essential in the current environment of severe business competition (Chen \& Zou, 2017).

Given the importance of selecting suppliers for business development, supplier selection research has mainly addressed two topics: definition of criteria and the selection problem itself (Erginel \& Gecer, 2016). However, as in (Bevilacqua et al., 2006) and (De Boer et al., 2001), the following points describe some of the topics 
considered strategic in supplier selection: evolution in supplier-customer relationships/problem definition; the definition of evaluation criteria for the specific situation; procedural problems / candidate pre-selection and decision model / final choice evaluation.

In addition, the supplier selection process involves a variety of quantitative and qualitative criteria, some of which are conflicting such as quality and cost (Hamdan \& Cheaitou, 2017), rather than considering a single factor, which is usually cost (Ho et al., 2010). As a consequence, quantitative techniques for supplier selection have been used to address this problem such as: mathematical programming, fuzzy set theory, multi-criteria decision making, artificial neural networks, and various integrated solutions that combine these approaches (Awasthi et al., 2018; Govindan et al., 2015; De Boer et al., 2001).

Although there are many studies on supplier selection and evaluation, there have been few studies in the textile sector and which addresses the Triple Bottom Line (TBL) methodology. The TBL integrates the economic, environmental and social aspects of sustainability (Elkington, 1998), since sustainability becomes a source of values in organizations, which makes it an important factor when evaluating suppliers. Reuter et al. (2010) emphasize that organizations that do not care about sustainable aspects at the time of supplier evaluation can cause harm to organizations, for instance, damage to the corporate image.

Therefore, this paper proposes the use of a specific Problem Structuring Method (PSM) - The Value-Focused Thinking (VFT) methodology - to identify criteria according to the values of the Decision Maker (DM) and to incorporate the TBL dimensions. Moreover, the use of the veto concept allows the decision maker to avoid selecting alternatives (suppliers) with undesirable values on specific critical criteria. Finally, because in supplier selection problems the choice of one unique supplier may be not enough to the aim of the DM, this paper utilizes a multicriteria method based on Flexible and Interactive Tradeoff (FITradeoff) elicitation process, within the ranking problematic perspective.

This paper is structured as follows. Section 2 provides a background on supplier selection, sustainability in supplier selection and multi-criteria decision-making (MCDM) in supplier selection. Section 3 describes the proposed framework for solving the supplier selection problem. Section 4 is dedicated to the case study, that is, to the application of the framework in a textile company in Campina Grande, Brazil. Section 5 discusses the results, suggests future works, and presents final conclusions.

\section{Background}

\subsection{Supplier selection}

According to (Govindan et al., 2015), as organizations started to focus on core competences and to outsource less profitable activities to supply chain partners, supplier selection became highly relevant to supply chain management (Segura \& Maroto, 2017). The selection of suppliers is essentially a process that involves a decision on a set of potential alternatives, which, depending on the current situation of the buyer company, may involve either the search for new suppliers or the screening/reduction of the existing set (De Boer et al., 2001; Wu \& Barnes, 2011).

It is essential that organizations select suppliers according to their strategic objectives, as well as maintaining cooperative relationships with them (Wan et al., 2017). Moreover, supplier selection must ensure a reliable supplier who has a low level of risk and who maximizes the value of the acquisition for the buyer (Monczka et al., 2010). There must also be good collaboration between buyer-supplier (Sarkis \& Talluri, 2002).

Kannan et al. (2013) argue that the activity of identifying and selecting suppliers has become more complex because suppliers have restrictions. Therefore, the problem of supplier selection has gained particular importance over recent decades, and a number of methods to make decision-making processes more effective have been developed (Zeydan et al., 2011). The decision-making process is more complex because it considers multiple criteria to meet a variety of objectives that are often conflicting, both quantitative and qualitative. For these reasons, Multi-Criteria Decision Analysis (MCDA) is most suitable for this type of situation (Almeida, 2013).

\subsection{Sustainability in supplier selection}

Through the need to adopt a new paradigm for society, such as development that meets the needs of the present without compromising the ability of future generations (Donato, 2008), sustainability is a term that has been gaining more and more prominence. Thus, organizations are being forced, through governmental, legal, social and market pressures (Barbieri et al., 2010), to incorporate sustainable practices. Nonetheless, these organizations are also realizing the importance of protecting the environment and ensuring the safety and well-being of current and future generations, in harmony with economic benefits (Gunasekaran \& Spalanzani, 2011). 
Therefore, several organizations have considered the supply chain as a strategic factor to optimize their sustainability profile, mainly due to the importance of their partners' sustainable responsibility for their own development (Bai \& Sarkis, 2010; Ageron et al., 2012). Even so, the management of sustainability is still considered a big challenge (Ehrgott et al., 2011). In this sense, organizations must innovate in the way they act to minimize or remedy negative impacts related to social and environmental aspects.

In the case of supplier selection, which is considered one of the most complex problems in the supply chain (Schütz et al., 2009; Corominas et al., 2015), one of the approaches to be used is the triple bottom line (TBL). It considers the three pillars of sustainability which are economic, environmental and social, and thus is the basis for sustainable development (Helleno et al., 2017; Slaper \& Hall, 2011). For Mota et al. (2018), the TBL is a decision support tool for the design and planning of sustainable supply chains, aiming synergistically to obtain effective actions. For Bai \& Sarkis (2010), the organization adopting this approach, in addition to resulting in long-term economic benefits, also acquires a competitive advantage. In this sense, it is quite significant to incorporate the aspects of TBL in the evaluation of suppliers.

\subsection{MCDM in supplier selection}

In supply chain management, supplier selection can be treated as a type of hierarchical multi-criteria decision-making (MCDM) problem because it involves various criteria and there is an hierarchical structure among criteria (Lima Júnior et al., 2013; Kannan et al., 2013; Wan et al., 2017). Criteria also often conflict, so a trade-off is necessary (Xia \& Wu, 2007; Wan et al., 2015; 2016).

For example, Dickson (1966) performed a multi-criteria analysis for supplier selection using 23 criteria (quality, delivery, performance, guarantee policies, production capacity, and price, among others). Table 1 presents a list of criteria for supplier selection that have been used in previous research.

Table 1. Criteria for supplier selection.

\begin{tabular}{|c|c|}
\hline Criteria & References \\
\hline Quality & $\begin{array}{l}\text { Lee (2009), Boran et al. (2009), Chen (2011), Liao \& Kao (2011), Ozkok \& Tiryaki (2011), Shemshadi et al. (2011), Yang \& } \\
\text { Tzeng (2011), Punniyamoorthy et al. (2011) }\end{array}$ \\
\hline Price & $\begin{array}{l}\text { Sanayei et al. (2010), Chen \& Yang (2011), Shemshadi et al. (2011), Yeh \& Chuang (2011), Amid et al. (2011), Chen (2011), } \\
\text { Fazlollahtabar et al. (2011), Jolai et al. (2011), Ozkok \& Tiryaki (2011), Kilincci \& Onal (2011) }\end{array}$ \\
\hline Delivery deadline & $\begin{array}{l}\text { Zhang et al. (2009), Lee (2009), Boran et al. (2009), Ordoobadi (2009), Liao \& Kao (2010), Sanayei et al. (2010), Park et al. } \\
\text { (2010), Khaleie et al. (2012), Yayla et al. (2012) }\end{array}$ \\
\hline Technology capacity & Shen \& Yu (2009), Feng et al. (2010), Sanayei et al. (2010), Park et al. (2010), Khaleie et al. (2012) \\
\hline Production capacity & $\begin{array}{l}\text { Sarkara \& Mohapatra (2006), Göl \& Çatay (2007), Liaoa \& Rittscher (2007), Chan \& Kumar (2007), Lin et al. (2009), Jafari } \\
\text { Songhori et al. (2011), Kilincci \& Onal (2011), Punniyamoorthy et al. (2011), Lee et al. (2015) }\end{array}$ \\
\hline Customer service & Chang et al. (2006), Ting \& Cho (2008), Liao \& Kao (2010), Amid et al. (2011) \\
\hline Flexibility & Lee (2009), Keskin et al. (2010), Sanayei et al. (2010), Yayla et al. (2012), Lee et al. (2015), \\
\hline Credibility & Birgün Barla (2003), Levary (2007), Göl \& Çatay (2007), Chen (2008), Liao \& Kao (2011) \\
\hline
\end{tabular}

According to Govindan et al. (2015), researchers have used several multiple criteria methods and decision tools for supplier selection, such as analytical hierarchy process (AHP) (Kilincci \& Onal, 2011; Dweiri et al., 2016), analytic network process (ANP) (Wan et al., 2017), multi-objective genetic algorithms (MOGA) (Yeh \& Chuang, 2011), Data Envelopment Analysis (DEA) (Chen, 2011; Liu \& Hai, 2005), Multi Attribute Decision Analysis (MADA) (Chen, 2011), TOPSIS (Boran et al., 2009), ELECTRE (Wan et al., 2017), Fuzzy Logic (Erginel \& Gecer, 2016), and linear programming (Bohner \& Minner, 2017).

While these methods and tools have many advantages in dealing with supplier selection, there are usually some difficulties and challenges. For example, it may be difficult to assign criteria weights and it is important to use appropriate methods to support decisions in organizations. In the next section, a framework based on the FITradeoff procedure is proposed to solve the supplier selection problem which requires less information and consequently, less cognitive effort from the DM.

\section{Proposed framework}

The proposed approach for supplier selection for this study is based on the twelve steps suggested by de Almeida et al. (2015) for resolving MCDM problems and consists in a framework with three main phases: i) problem formulation: in which the main elements are approached; ii) problem development: in which the preference 
modeling is conducted; and iii) finalization: in which the final steps for problem resolution are developed, including evaluation and final discussion. The framework is shown in Figure 1.

In the first phase of the framework, there are four preliminary steps: i) contextualization involves the formulation of the information of the problem, which has a direct influence on the design of the decision procedure; ii) characterization of the DM gathers information about how many DM's will be required for the procedure, and who they are; iii) definition of the criteria refers to the choice of criteria used in decision making, which in this case involved the VFT method to identify criteria according to the values of the DM and then integrates the TBL concepts which involves the economic, social and environmental dimensions; and iv) definition of the method, which in this case involved a family of methods that best suited the context of the analysis.

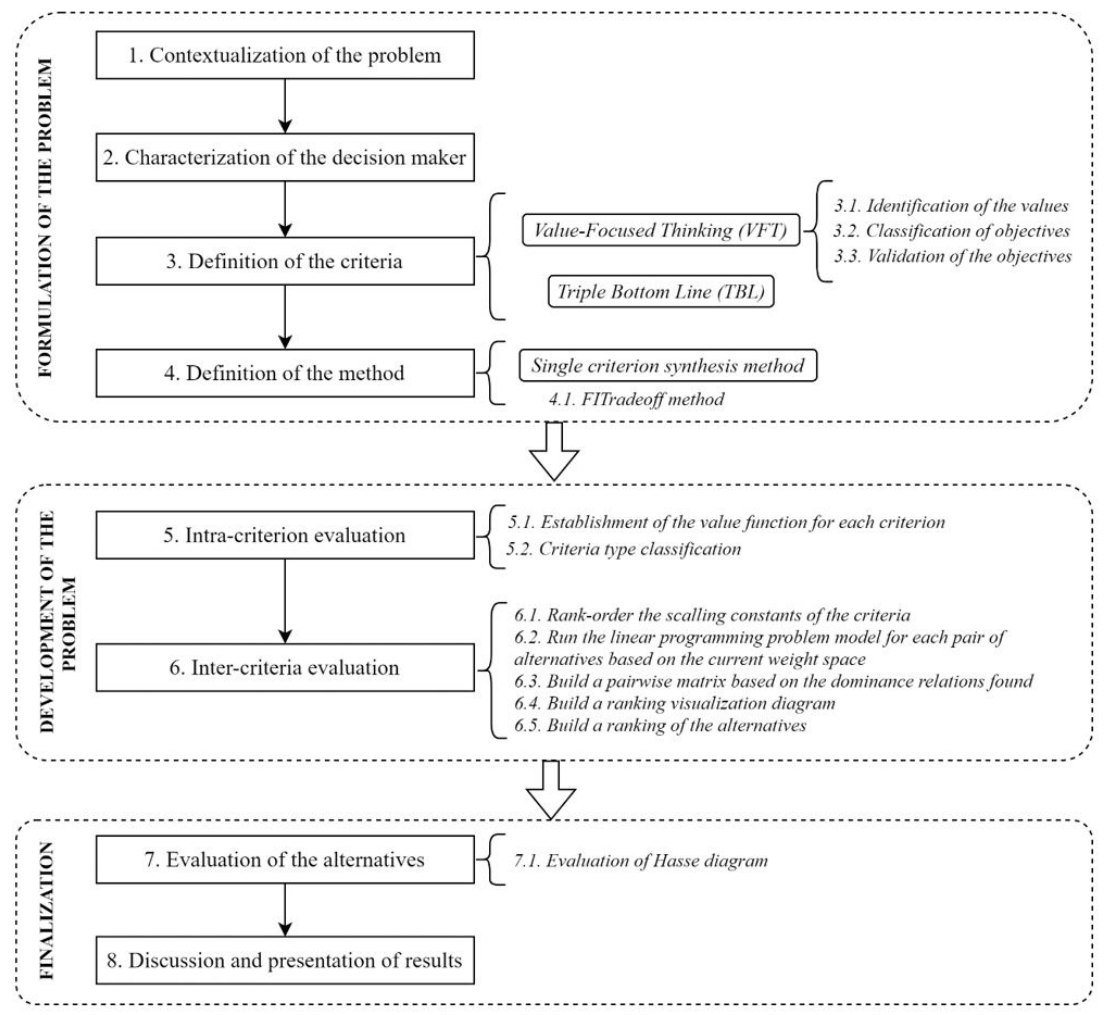

Figure 1. Framework for solving the supplier selection problem.

The second phase of the framework, the development of the problem, is divided into two steps: (i) intra-criterion evaluation: the problem is developed through the elicitation of value functions, which is related to the value of different performances of outcomes in all criteria. In this step the information will be given in the decision matrix; and ii) inter-criteria evaluation: in this step, based on the multicriteria method already established, the method must be parameterized, that is, the information that allows the quantitative combination of the criteria for the aggregation process to evaluate the alternatives must be obtained.

Finally, in the last phase, which is the resolution of the problem, there are two final steps: i) evaluation of the alternatives, which in this case involved obtaining an ordering of suppliers; and ii) presentation of the discussions and analysis of the results obtained.

\section{Proposal application}

In order to illustrate the applicability of the proposed framework, this section presents a real supplier selection problem following the steps described in the previous section. This section details how each method can be applied in the framework: the VFT method is used for structuring the objectives and criteria, and for integrating the TBL dimensions within the problem; the FITradeoff method is used to support the decision-making process with a simpler visualization of dominance relations, obtaining a complete order (or preorder) of the suppliers. 


\subsection{Contextualization of the problem}

The case study was conducted in a small textile company in the city of Campina Grande, Brazil, which manufactures children's clothing for the regional market, the Northeast of Brazil. The company was founded in 1992 and its main raw material is knitwear. Because of the importance and the value-added by this raw material for the company, this decision problem focuses on the selection of knitwear suppliers from among the current and former suppliers of the company. The main point of this research is to analyze the supplier selection process, taking into consideration several aspects, and to improve the decision process in order to increase the profitability of the company, as well as to meet the expectations of its clients.

The company currently uses an ad-hoc method (Figure 2) for conducting the process of supplier selection, which always occurs before the launch of new collections on a seasonal basis, and which is restricted to the suppliers that already have a relationship with the company. In this research, fifteen potential suppliers were identified by the organization's purchasing department (suppliers $F_{1}$ to $F_{15}$ ), including current and former suppliers. The supplier selection process is conducted jointly by the purchasing, production and financial departments, and takes into account four factors: the mix of the samples of the meshes (in terms of colors and styles), followed by the joint analysis of price, quality and time.

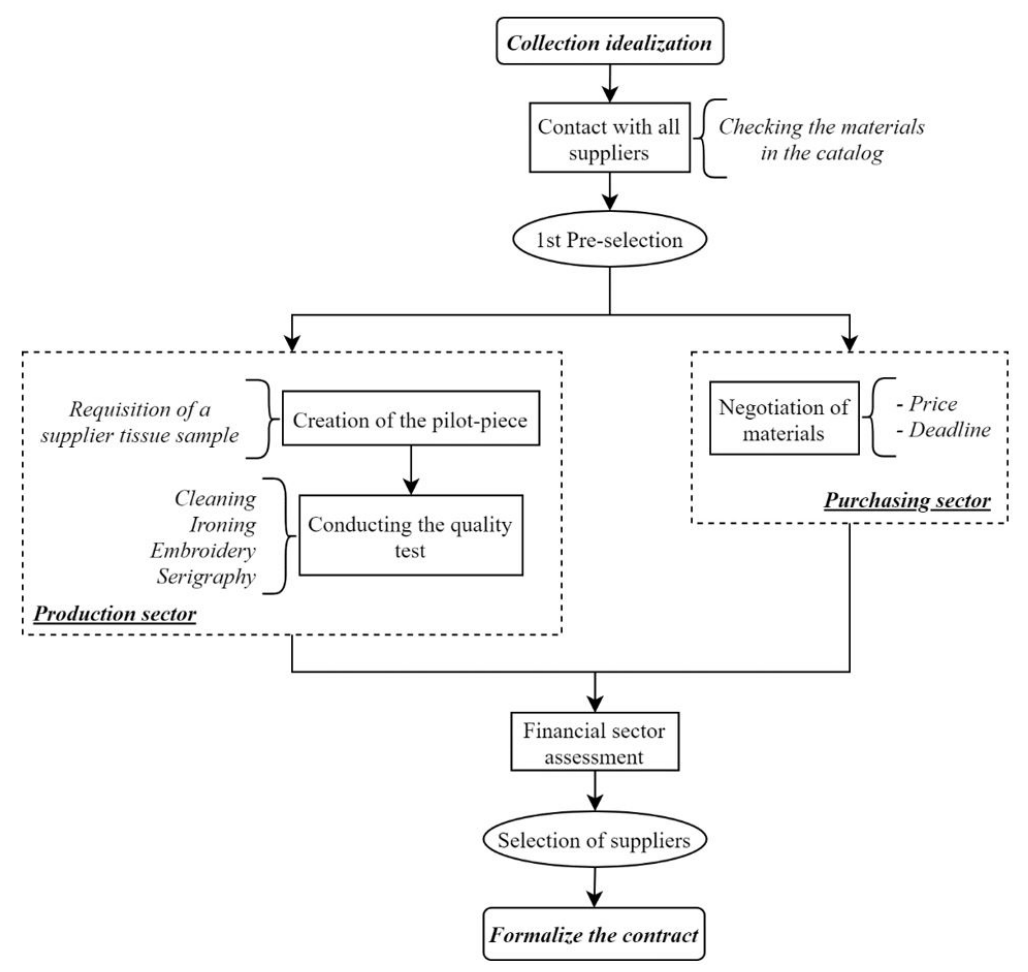

Figure 2. Current process of supplier selection in the company under analysis.

\subsection{Characterization of the decision maker}

This problem will be analyzed from the perspective of a single DM, who is the manager of the production department of the organization. The choice was based on her vast experience in the clothing sector, and the fact that the manager is directly in contact with suppliers.

\subsection{Criteria definition}

In this step, the criteria that correspond to the most significant aspects will be identified to evaluate the performance of suppliers. The values of the decision-maker must be identified, structured, and clarified. Alencar et al. (2011), emphasize that the VFT methodology is one of the most suitable methodologies for 
clarifying the objectives and to specify the consequences of a decision problem. This methodology is especially important because it seeks to identify criteria that are not yet explored. Thus, the VFT methodology will be applied in this study to extract the objectives, and then to obtain the criteria that represent the desires/objectives of the DM. The application of the VFT in this research is based on an adaptation of the procedure proposed by Alencar et al. (2011), according to the following steps:

a. Identification of values: A semi-structured questionnaire based on the techniques proposed by (Keeney, 1996) was applied to the DM. The questions are shown in Table 2 and were developed to identify the primary values that the DM should use in the process of supplier evaluation:

Table 2. Questionnaire for eliciting the values of the decision maker.

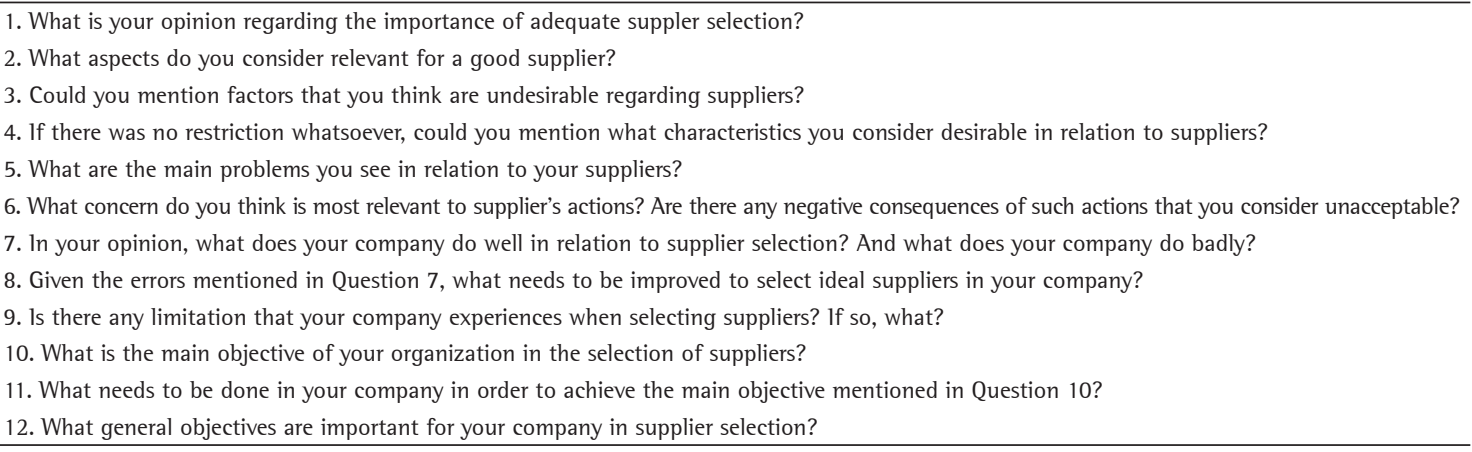

b. Classification of objectives: After the identification of values, the redundant objectives were eliminated. Then, in order to obtain a better understanding of the relationships among the objectives, they were hierarchized, as shown in Figure 3.

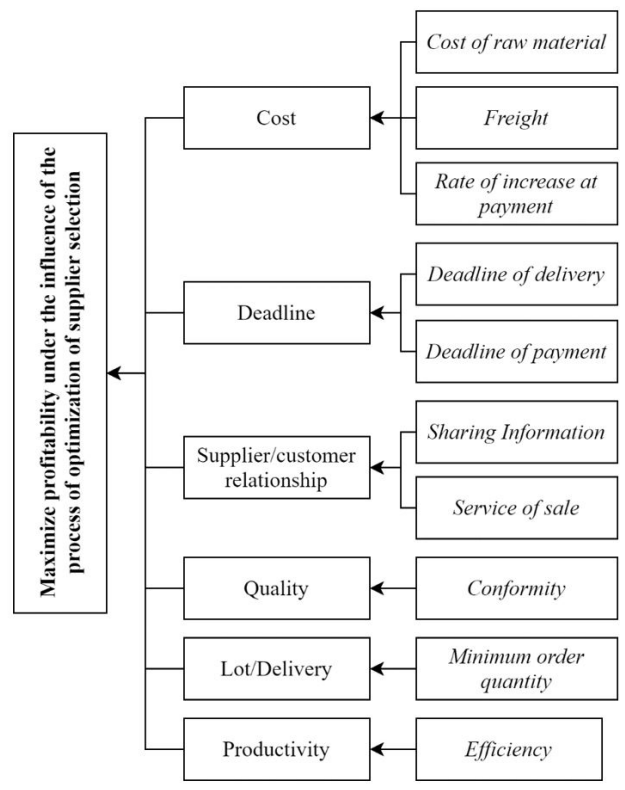

Figure 3. Value hierarchy for the decision maker.

From this hierarchy, one can divide the objectives into three types: fundamental, middle, and strategic goals. Strategic objectives lead to organizational decisions. The fundamental objectives correspond to the ends to which the DM's aspire. Middle objectives represent the ways to reach other objectives. For this company, the first level of objectives, the strategic goal, is to "Maximize profitability under the influence of the process of optimization 
of supplier selection". In the fundamental level there are six objectives: "Minimize costs"; "Improve deadlines"; "Maximize supplier/company relationship"; "Maximize quality"; "Minimize batch/delivery"; and "Maximize productivity". Finally, for the middle objectives, which are the sub-criteria and through which the fundamental objectives can be achieved, there are ten elements: cost of raw material, increase rate at payment, freight, delivery deadline, payment deadline, information sharing, sales service, conformity, minimum order quantity, and yield.

c. Confirmation of objectives: In this step, the objectives identified in the previous step are presented to the DM so that they can be confirmed. With the support of the VFT, it was possible to define a set of criteria and sub-criteria, as well as their classification, description and evaluation measures, as shown in Table 3. In this process, the VFT methodology had already identified some economic factors of the TBL.

Table 3. Criteria for the evaluation of alternatives based on VFT.

\begin{tabular}{|c|c|c|c|c|}
\hline Criterion & & Subcriterion & Direction & Description and measurement \\
\hline \multirow{3}{*}{ Cost } & $C_{1}$ & Raw material cost & Minimization & The average price (Brazilian currency- $\mathrm{R} \$ / \mathrm{Kg}$ ) \\
\hline & $\mathrm{C}_{2}$ & Freight & Maximization & $\begin{array}{l}\text { The type of freight: FOB (Free on Board) or CIF (Cost, } \\
\text { Insurance and Freight) }\end{array}$ \\
\hline & $\mathrm{C}_{3}$ & Rate added & \multirow[b]{2}{*}{ Minimization } & Rate $(\%)$ added in each additional payment quota \\
\hline \multirow[t]{2}{*}{ Deadline } & $\mathrm{C}_{4}$ & Delivery deadline & & $\begin{array}{l}\text { Number of days between the day of purchase order and the } \\
\text { day of product delivery }\end{array}$ \\
\hline & $\mathrm{C}_{5}$ & Payment deadline & \multirow{4}{*}{ Maximization } & Number of days for payment \\
\hline \multirow{2}{*}{ Customer/supplier relationship } & $\mathrm{C}_{6}$ & Information sharing & & Information shared by supplier to update collections and trends \\
\hline & $\mathrm{C}_{7}$ & Sales service & & Service during and after-sales \\
\hline Quality & $\mathrm{C}_{8}$ & Conformity & & $\begin{array}{l}\text { Evaluation of product requests regarding quality and } \\
\text { conformity }\end{array}$ \\
\hline Lot/delivery & $\mathrm{C}_{9}$ & $\begin{array}{l}\text { Minimum order } \\
\text { quantity }\end{array}$ & Minimization & Minimum order quantity $(\mathrm{Kg})$ of the supplier \\
\hline Productivity & $\mathrm{C}_{10}$ & Efficiency & Maximization & Tissue yield (meters/Kg) \\
\hline
\end{tabular}

More information is needed to make decisions than is shown in Table 3. For example, regarding the freight criterion $\left(C_{2}\right)$, the evaluation was based on the work of Frej \& Almeida (2016). However, CIF is preferred to FOB, because in this case the supplier assumes the responsibility for the costs and risks involved in transporting the product. Therefore, for this paper, suppliers whose freight is CIF received a value of 1 and suppliers whose freight is FOB received a value between 0.5 and 1, depending on the assessment of the supplier's credibility in the market.

Being that, apart from all these factors considered through VFT, it is essential to consider an appropriate balance amongst economic, environmental and social objectives. This can be done through the use of the triple bottom line (TBL), given that many studies have tried to explore sustainable development through the use of TBL to change the ideology of sustainability to the operational level, considering multiple aspects and seeking as a result the benefits and competitive advantages offered by the respective approach (Pagell \& Gobeli, 2009; Gimenez et al., 2012; Su et al., 2016; Shi et al., 2017). Table 4 below presents the environmental and social criteria selected in accordance with TBL.

Table 4. Criteria for the evaluation of alternatives based on TBL.

\begin{tabular}{|c|c|c|c|c|}
\hline Criterion & & Subcriterion & Direction & Description and measurement \\
\hline \multirow[t]{2}{*}{ Environmental } & $C_{11}$ & Reuse & \multirow{5}{*}{ Maximization } & $\begin{array}{l}\text { Refers to the assessment of how the various means for prolonging the } \\
\text { practical service life of textile products, with or without prior modification, } \\
\text { be used. }\end{array}$ \\
\hline & $\mathrm{C}_{12}$ & Packaging reduction & & $\begin{array}{l}\text { Valuation of the minimum use of packaging material containing less toxic } \\
\text { materials. }\end{array}$ \\
\hline \multirow{3}{*}{ Social } & $\mathrm{C}_{13}$ & Training & & $\begin{array}{l}\text { Assessment of programs to help employees learn specific knowledge or skills } \\
\text { to improve performance in their current roles. }\end{array}$ \\
\hline & $\mathrm{C}_{14}$ & $\begin{array}{l}\text { Community } \\
\text { donation }\end{array}$ & & Appreciation of the donations and in-kind support to community. \\
\hline & $C_{15}$ & Safety practices & & $\begin{array}{l}\text { Evaluation of the use of safe work practices (methods outlining how } \\
\text { to perform a task with minimum risk to people, equipment, materials, } \\
\text { environment, and processes). }\end{array}$ \\
\hline
\end{tabular}


Moreover, due to their qualitative nature, the criteria information sharing $\left(C_{6}\right)$, sales service $\left(C_{7}\right)$, conformity $\left(C_{8}\right)$, Reuse $\left(\mathrm{C}_{11}\right)$, Packaging reduction $\left(\mathrm{C}_{12}\right)$, Training $\left(\mathrm{C}_{13}\right)$, Community donation $\left(\mathrm{C}_{14}\right)$ and Safety practices $\left(\mathrm{C}_{15}\right)$ were evaluated according to a five-point Likert scale (Table 5).

Table 5. Qualitative criteria description.

\begin{tabular}{ccc}
\hline & Criteria & Evaluation \\
\hline$C_{6}$ & Information sharing & \\
$C_{7}$ & Sales service & Five-point scale: \\
$C_{8}$ & Conformity & 1. Very bad \\
$C_{11}$ & Reuse & 2. Bad \\
$C_{12}$ & Packaging reduction & . Regular \\
$C_{13}$ & Training & 5. Very good \\
$C_{14}$ & Community donation \\
$C_{15}$ & Safety practices & \\
\hline
\end{tabular}

\subsection{Definition of method}

In a multi-criteria decision-making process, the definition of the method to be used is critical. According to Almeida (2013), several aspects must be taken into account in choosing the multi-criteria method, such as: rationality, preference structure and the problematic.

The following three aspects was identified in the supplier problem analyzed in this paper: (i) the compensatory rationality of the DM: a low performance on one criterion can be compensated by a high performance on other criteria; (ii) the fact that the DM does not have a well-defined preference structure, i.e., the case of incomplete (or partial) information (Frej et al., 2019); and (iii) the ranking nature of the problem (ranking problematic - P $\gamma$ ) - Supplier prioritization. Considering these aspects, the multi-criteria approach that best fits the context under analysis is the single-criterion synthesis, which aggregates the criteria into a single synthesis criterion, such as the value or utility of the alternatives (Roy, 1996). Finally, the FlTradeoff method (Almeida et al., 2016; Almeida Filho et al., 2017) was considered suitable for the present analysis for a number of reasons:

- It uses the concept of flexible elicitation embedded in a decision support system;

- The nature of the information requested is cognitively easier for the DM to understand;

- It reduces the amount of information required from the DM; and

- It leads to fewer inconsistencies during the elicitation process.

Finally, according to Frej et al. (2019), an important aspect of the FlTradeoff method is its flexibility. Indeed, the DM may move on to a new question, if he/she feel uncomfortable during the elicitation process. This fact, however, do not cause loss of information in the decision-making process.

\subsection{Intra-criteria evaluation}

In this step, the evaluation matrix was obtained, which is composed of all the value functions $\left(v_{j}\left(a_{i}\right)\right)$ that correspond to the evaluation of each alternative $i$ according to each criterion $j$. Table 6 shows the evaluation matrix for the present analysis. In order to obtain this information, technical visits and meetings with the DM were arranged using structured interviews and documentary analysis.

It is well known that more participants in a company's supply chain lead to more resources required to manage it. Therefore, the limited number of registered suppliers facilitates control activities. And in this sense, it is possible to monitor the supply and transportation processes, as well as assessing the performance evaluation of each partner. Moreover, the restructuring and consolidation of the number of suppliers contributes to the building of partnership with the set of companies with which one company really wants to develop a collaborative relationship with a synergistic result. For this case study, the decision-maker is not interested in partnerships with suppliers that have low performance on some criteria, such as raw material cost $\left(C_{1}\right)$ and minimum quantity of order $\left(\mathrm{C}_{9}\right)$, as shown in Table 7 . 
Table 6. Evaluation matrix for the supplier selection problem.

\begin{tabular}{|c|c|c|c|c|c|c|c|c|c|c|c|c|c|c|c|}
\hline \multirow{2}{*}{ Alternatives } & \multicolumn{15}{|c|}{ Criteria } \\
\hline & $C_{1}$ & $\mathrm{C}_{2}$ & $\mathrm{C}_{3}$ & $\mathrm{C}_{4}$ & $C_{5}$ & $\mathrm{C}_{6}$ & $\mathrm{C}_{7}$ & $\mathrm{C}_{8}$ & $\mathrm{C}_{9}$ & $C_{10}$ & $C_{11}$ & $C_{12}$ & $C_{13}$ & $C_{14}$ & $C_{15}$ \\
\hline$F_{1}$ & 39.00 & 1.0 & 3.50 & 18 & 60 & 4 & 4 & 5 & 100 & 3.58 & 4 & 4 & 4 & 2 & 4 \\
\hline $\mathrm{F}_{2}$ & 42.70 & 1.0 & 4.95 & 35 & 75 & 3 & 4 & 4 & 110 & 4.10 & 4 & 5 & 4 & 1 & 5 \\
\hline $\mathrm{F}_{3}$ & 32.67 & 1.0 & 3.25 & 30 & 60 & 3 & 3 & 3 & 120 & 3.20 & 3 & 2 & 4 & 1 & 4 \\
\hline $\mathrm{F}_{4}$ & 43.00 & 1.0 & 5.30 & 40 & 60 & 2 & 4 & 4 & 150 & 3.18 & 2 & 2 & 3 & 3 & 4 \\
\hline $\mathrm{F}_{5}$ & 31.50 & 1.0 & 5.40 & 15 & 60 & 1 & 1 & 2 & 100 & 3.30 & 3 & 1 & 3 & 3 & 3 \\
\hline $\mathrm{F}_{6}$ & 40.86 & 0.8 & 2.70 & 30 & 60 & 4 & 4 & 4 & 140 & 3.43 & 3 & 4 & 3 & 2 & 4 \\
\hline $\mathrm{F}_{7}$ & 43.28 & 0.8 & 2.55 & 35 & 60 & 3 & 4 & 4 & 130 & 3.98 & 4 & 3 & 4 & 1 & 4 \\
\hline $\mathrm{F}_{8}$ & 31.68 & 0.9 & 3.55 & 40 & 75 & 5 & 5 & 5 & 120 & 3.79 & 4 & 5 & 3 & 2 & 5 \\
\hline $\mathrm{F}_{9}$ & 44.32 & 1.0 & 3.60 & 30 & 75 & 4 & 4 & 4 & 140 & 3.29 & 5 & 4 & 3 & 1 & 5 \\
\hline$F_{10}$ & 43.39 & 1.0 & 4.30 & 20 & 90 & 4 & 3 & 3 & 120 & 3.61 & 3 & 3 & 3 & 3 & 4 \\
\hline$F_{11}$ & 34.90 & 1.0 & 4.20 & 30 & 60 & 3 & 3 & 2 & 130 & 3.20 & 3 & 2 & 3 & 3 & 3 \\
\hline$F_{12}$ & 34.39 & 1.0 & 3.45 & 40 & 60 & 4 & 4 & 4 & 150 & 3.70 & 2 & 1 & 2 & 2 & 3 \\
\hline $\mathrm{F}_{13}$ & 34.40 & 0.7 & 5.20 & 25 & 90 & 2 & 4 & 3 & 110 & 4.18 & 3 & 1 & 4 & 2 & 5 \\
\hline $\mathrm{F}_{14}$ & 50.49 & 1.0 & 5.15 & 45 & 75 & 4 & 3 & 2 & 120 & 3.25 & 4 & 2 & 2 & 1 & 5 \\
\hline$F_{15}$ & 35.53 & 0.9 & 4.00 & 45 & 75 & 3 & 4 & 4 & 140 & 3.57 & 2 & 1 & 3 & 1 & 4 \\
\hline
\end{tabular}

Table 7. Vetos for criteria.

\begin{tabular}{ccc}
\hline Veto & Raw material cost $\left(\mathrm{C}_{1}\right)$ & Minimum quantity by order $\left(\mathrm{C}_{\mathrm{g}}\right)$ \\
\hline Lower bound & 43 Brazilian currency $(\mathrm{R} \$) /$ meter & $140 \mathrm{Kg}$ \\
\hline
\end{tabular}

Finally, it is possible to apply the concept of veto in the evaluation matrix. Hence, some alternatives (six out of a total of 15) will be penalized in the analysis for having undesirable values in both or just one of the two criteria $\mathrm{C}_{1}$ and $\mathrm{C}_{9}: \mathrm{F}_{4}, \mathrm{~F}_{7}, \mathrm{~F}_{9}, \mathrm{~F}_{10}, \mathrm{~F}_{12}, \mathrm{~F}_{14}$.

\subsection{Inter-criteria evaluation}

The inter-criteria evaluation can be performed in the FITradeoff (Flexible and Interactive Tradeoff) decision support system (DSS) which is available to download by request (Universidade Federal de Pernambuco, 2019). The first step is the criteria (constant scale) ranking by the DM, which is based on a full evaluation of the criteria and considering the value range of each criterion. The ranking obtained was: $\mathrm{C}_{8}>\mathrm{C}_{1}>\mathrm{C}_{10}>\mathrm{C}_{5}>\mathrm{C}_{3}>\mathrm{C}_{4}>\mathrm{C}_{9}>\mathrm{C}_{2}>\mathrm{C}_{7}>\mathrm{C}_{6}>\mathrm{C}_{13}>\mathrm{C}_{12}>\mathrm{C}_{15}>\mathrm{C}_{11}>\mathrm{C}_{14}$. It is worth stating that this information is used as a constraint into the linear programming problem model, in a way that allows the model to search for dominance relations among alternatives, that is, a flexible elicitation is performed in which the DM answers questions, in cycle iteration, considering tradeoffs between consequences, declaring strict preference relations between them, and then the information obtained from the DM's answers is used to update the weight space within each iteration.

However, differently from the choice problem that verifies the optimality potential of the alternatives, the ranking problem employs the idea of paired dominance relations among the alternatives within the current weight space, so that it is possible to establish preferential relations among the alternatives to obtain a partial or complete order in each iteration with the DM.

The heuristic present in the FITradeoff procedure reduces inconsistencies and the effort required for the DM during each interaction. For example, instead of evaluating $3 *$ (number of criteria -1 ) indifference relations (which corresponds to 42 interactions) using the traditional tradeoff procedure, only 20 cycles were required using FlTradeoff, as shown in Table 8. Where $X_{i}$ represents a result between the best and the worst performance for criterion $C_{i}$, and $B_{i}$ represents the best result for criterion $C_{i}$.

The FITtradeoff software also provides: (i) the range of values for the scale constants in descending order, giving the minimum and maximum value that each constant can assume, and (ii) the scaling constant value that maximizes the overall value of the alternative. This information is shown in Figure 4. 
Table 8. Interactions and choices with veto concept of the decision maker.

\begin{tabular}{|c|c|c|c|c|c|c|c|}
\hline \multirow{2}{*}{$\frac{\text { Cycle }}{1}$} & \multicolumn{2}{|c|}{ Consequence $\mathrm{A}$} & \multicolumn{2}{|c|}{ Consequence B } & \multirow{2}{*}{$\frac{\text { Choice }}{\text { A }}$} & \multirow{2}{*}{$\begin{array}{c}\text { Number of } \\
\text { questions }\end{array}$} & \multirow{2}{*}{$\begin{array}{c}\text { Ranking levels } \\
1\end{array}$} \\
\hline & $C_{1}$ & $X_{1}=4$ & $C_{15}$ & $\mathrm{~B}_{15}=3$ & & & \\
\hline 2 & $C_{1}$ & $X_{1}=4$ & $\mathrm{C}_{2}$ & $\mathrm{~B}_{2}=31.5$ & A & 2 & 1 \\
\hline 3 & $\mathrm{C}_{2}$ & $X_{2}=37.1$ & $\mathrm{C}_{3}$ & $\mathrm{~B}_{3}=4.18$ & A & 3 & 3 \\
\hline 4 & $\mathrm{C}_{3}$ & $X_{3}=3.69$ & $\mathrm{C}_{4}$ & $\mathrm{~B}_{4}=90$ & A & 4 & 5 \\
\hline 5 & $\mathrm{C}_{4}$ & $X_{4}=75$ & $\mathrm{C}_{5}$ & $B_{5}=2.7$ & A & 5 & 5 \\
\hline 6 & $C_{5}$ & $X_{5}=4.05$ & $\mathrm{C}_{6}$ & $B_{6}=15$ & B & 6 & 5 \\
\hline 7 & $\mathrm{C}_{6}$ & $X_{6}=30$ & $\mathrm{C}_{7}$ & $\mathrm{~B}_{7}=100$ & B & 7 & 5 \\
\hline 8 & $\mathrm{C}_{7}$ & $X_{7}=120$ & $\mathrm{C}_{8}$ & $\mathrm{~B}_{8}=1$ & B & 8 & 5 \\
\hline 9 & $\mathrm{C}_{8}$ & $X_{8}=0.85$ & $\mathrm{C}_{9}$ & $B_{9}=5$ & B & 9 & 5 \\
\hline 10 & $\mathrm{C}_{9}$ & $X_{9}=3$ & $C_{10}$ & $\mathrm{~B}_{10}=5$ & A & 10 & 5 \\
\hline 11 & $C_{10}$ & $X_{10}=3$ & $C_{11}$ & $\mathrm{~B}_{11}=4$ & A & 11 & 6 \\
\hline 12 & $C_{11}$ & $X_{11}=3.5$ & $C_{12}$ & $\mathrm{~B}_{12}=5$ & A & 12 & 6 \\
\hline 13 & $C_{12}$ & $X_{12}=3$ & $C_{13}$ & $\mathrm{~B}_{13}=5$ & A & 13 & 6 \\
\hline 14 & $C_{13}$ & $X_{13}=4$ & $C_{14}$ & $\mathrm{~B}_{14}=4$ & Indifferent & 14 & 6 \\
\hline 15 & $C_{14}$ & $X_{14}=3$ & $C_{15}$ & $\mathrm{~B}_{15}=3$ & Indifferent & 15 & 6 \\
\hline 16 & $C_{1}$ & $x_{1}=3$ & $\mathrm{C}_{2}$ & $B_{2}=31.5$ & B & 16 & 6 \\
\hline 17 & $\mathrm{C}_{2}$ & $X_{2}=39.9$ & $\mathrm{C}_{3}$ & $B_{3}=4.18$ & B & 17 & 6 \\
\hline 18 & $\mathrm{C}_{3}$ & $X_{3}=3.445$ & $\mathrm{C}_{4}$ & $\mathrm{~B}_{4}=90$ & A & 18 & 6 \\
\hline 19 & $\mathrm{C}_{4}$ & $X_{4}=67.5$ & $C_{5}$ & $B_{5}=2.7$ & A & 19 & 6 \\
\hline 20 & $C_{5}$ & $X_{5}=3.375$ & $\mathrm{C}_{6}$ & $B_{6}=15$ & B & 20 & 6 \\
\hline
\end{tabular}

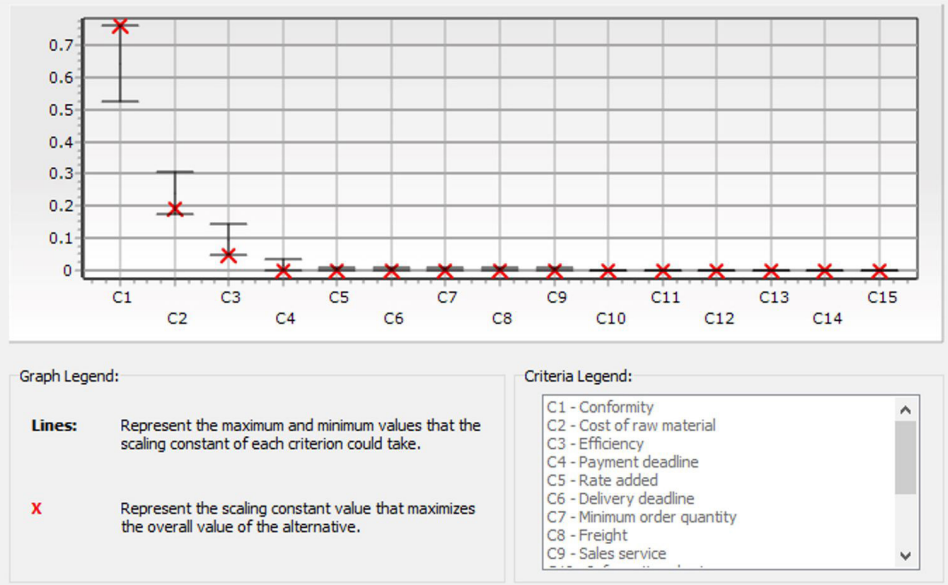

Figure 4. Range of values for scale constants.

\subsection{Evaluation of alternatives}

According to Figures 5a and 5b, it is possible to compare two different scenarios for the final ordering of the suppliers - with and without the use of the veto concept before the use of FlTradeoff method. They represent the graphical visualization tool (Hasse diagram), based on which a ranking of the alternatives is established. The Hasse diagram has the property of transitivity reduction; i.e., since it is an additive model (where there is transitivity), then, for ease of viewing by the decision maker, the diagram omits these "unnecessary" arrows. It should be noted that directed arrows indicate dominance relations, non-direct gray arrows indicate indifference relations and different ranking levels are separated by dashed lines. As can be seen, the use of veto concept eliminated six potential suppliers $\left(F_{4}, F_{7}, F_{9}, F_{10}, F_{12}, F_{14}\right)$. Second, the first two suppliers $\left(F_{8}\right.$ and $\left.F_{1}\right)$ remained in the same positions in the ranking, which reflects the fact that these suppliers have a good performance on all the criteria, regardless of vetoes. Similarly, $F_{11}$ and $F_{5}$ were in the last positions regardless of the use of the veto. 


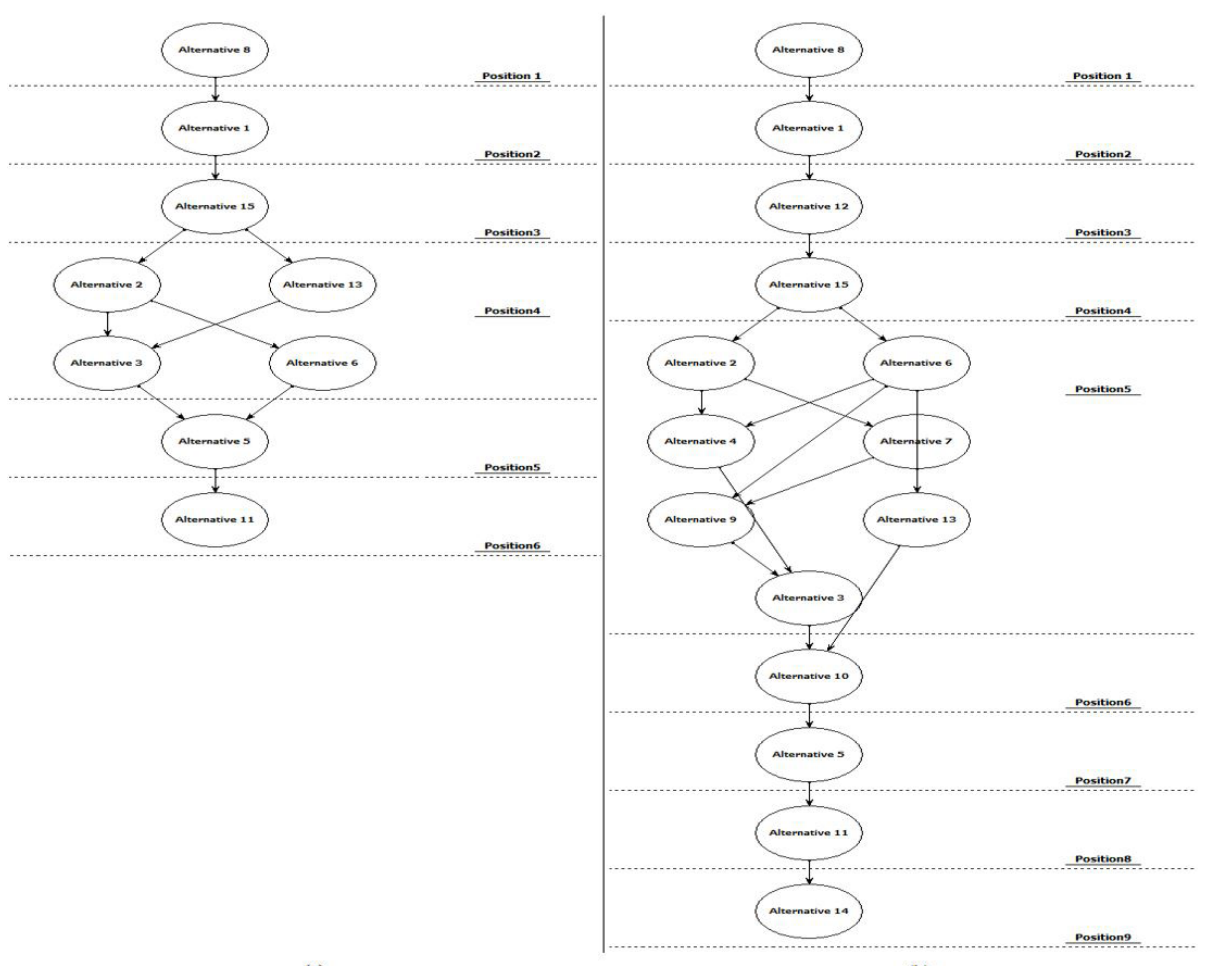

Figure 5. Final ranking of the suppliers.

\section{Discussion, conclusion and future research}

Selecting appropriate suppliers is a complex task that requires much effort and is critical because it can reduce the quality of the product and consequently the corporate image of the organization. According to the literature, the selection of suppliers must take into account multiple criteria, and although this problem has been well addressed, there is always space for adding further refinements.

In this paper, a supplier selection problem in a textile company in Campina Grande, Brazil was analyzed by means of a multicriteria approach using the Fitradeoff procedure for the problematic ranking. The selected method demands less cognitive effort but at the same time has a strong axiomatic structure. For the establishment of the criteria, TBL and VFT were used. The first integrates the economic, environmental and social dimensions that are the basis of sustainability. In this sense, TBL emerges as a tool to help organizations adapt to the new world context. In addition, the VFT was used to identify the criteria that are most important for the DM, and to provide an adequate model that best structures the decision problem. Therefore, it helps managers to identify decision-making opportunities that offer greater competitive advantages. Finally, this paper also incorporates the concept of veto which allows the DM to avoid selecting alternatives with undesirable values on some specific criteria.

With regard to the main findings of this paper, when comparing the results with and without the veto concept, there were some interesting aspects that should be highlighted. First, supplier $\mathrm{F}_{14}$, dominated by all other alternatives, was the worst evaluated in all criteria, once it was positioned in the last position in the ranking without veto, as well as it was eliminated by the veto. Second, although supplier $F_{12}$ remained in the third position in the ranking without veto, it was eliminated by the veto procedure. And, in this case $F_{15}$ remains in the third position with the application of the veto. This shows the compensatory effect of the traditional additive model, which means that these alternatives perform poorly on one or more criteria yet remaining well ranked in the final ordering because of the compensation of a good performance in other criteria. Third, it should be highlighted here that different from the ranking without the veto, in the ranking with veto $\mathrm{F}_{3}$ is dominated by $F_{13}$ and $F_{6}$ is dominated by $F_{2}$. However, they remain in the same group. In the ranking without the veto, 
they still incomparable to each other. Fourth, it is worth pointing out that the required effort and the time spent on this process by the DM are consistent with the objectives targeted by the method. Finally, the study demonstrates the importance of using appropriate methods to support better decision making in organizations, as can seen in this case study, since about the current suppliers, four of them $\left(F_{4}, F_{7}, F_{9}, F_{10}\right)$ was eliminated with the proposed method, and two of the former suppliers $\left(\mathrm{F}_{15}\right.$ and $\left.\mathrm{F}_{13}\right)$ appeared on a good positions in the ranking, respectively in the $4^{\text {th }}$ and $5^{\text {th }}$ position.

In conclusion, this study demonstrates the importance and advantage of using appropriate methods to support and improve multicriteria decision making in organizations, providing a best compromise recommendation. Future research should focus on group decision-making problems and other sectors.

\section{References}

Ageron, B., Gunasekaran, A., \& Spalanzani, A. (2012). Sustainable supply management: an empirical study. International Journal of Production Economics, 140(1), 168-182. http://dx.doi.org/10.1016/j.jpe.2011.04.007.

Alencar, L. H., Mota, C. M. D. E. M., \& Alencar, M. H. (2011). The problem of disposing of plaster waste from building sites: Problem structuring based on value focus thinking methodology. Waste Management, 31(12), 2512-2521. http://dx.doi.org/10.1016/j. wasman.2011.06.015. PMid:21816597.

Almeida, A. T. (2013). Decision making in organizations: Building multicriteria decision models. Sao Paulo: Atlas.

Almeida, A. T., Almeida, J. A., Costa, A. P. C. S., \& Almeida-Filho, A. T. (2016). A new method for elicitation of criteria weights in additive models: Flexible and interactive tradeoff. European Journal of Operational Research, 250(1), 179-191. http://dx.doi.org/10.1016/j. ejor.2015.08.058.

Almeida, A. T., Cavalcante, C. A. V., Alencar, M. H., Ferreira, R. J. P., Almeida-Filho, A. T., \& Garcez, T. V. (2015). Multicriteria and multiobjective models for risk, reliability and maintenance decision analysis. (International Series in Operations Research and Management Science). New York: Springer. https://doi.org/10.1007/978-3-319-17969-8.

Almeida-Filho, A. T., de Almeida, A. T., \& Costa, A. P. C. S. (2017). A flexible elicitation procedure for additive model scale constants. Annals of Operations Research, 259(1-2), 65-83. http://dx.doi.org/10.1007/s10479-017-2519-y.

Amid, A., Ghodsypour, S. H., \& O’Brien, C. (2011). A weighted max- min model for fuzzy multi-objective supplier selection in a supply chain. International Journal of Production Economics, 131(1), 139-145. http://dx.doi.org/10.1016/j.jpe.2010.04.044.

Awasthi, A.; Govindan, K.; Gold, S. (2018). Multi-tier sustainable global supplier selection using a fuzzy AHP-VIKOR based approach. International Journal of Production Economics, 195, 106-117. https://doi.org/10.1016/j.jpe.2017.10.013

Bai, C., Sarkis, J. (2010). Integrating sustainability into supplier selection with grey system and rough set methodologies. International Journal of Production Economics. 124, 252-264. https://doi.org/10.1016/j.jpe.2009.11.023

Barbieri, J. C., Vasconcelos, I. F. G., Andreassi, A., \& Vasconcelos, F. C. (2010). Innovation and sustainability: new models and propositions. Journal of Business Administration, 50(2), 146-154. http://dx.doi.org/10.1590/S0034-75902010000200002.

Bevilacqua, M., Ciarapica, F. E., \& Giacchetta, G. (2006). A fuzzy-QFD approach to supplier selection. Journal of Purchasing and Supply Management, 12(1), 14-27. http://dx.doi.org/10.1016/j.pursup.2006.02.001.

Birgün Barla, S. (2003). A case study of supplier selection for lean supply by using a mathematical model. Logistics Information Management, 16(6), 451-459. http://dx.doi.org/10.1108/09576050310503420.

Bohner, C., \& Minner, S. (2017). Supplier selection under failure risk, quantity and business volume discounts. Computers \& Industrial Engineering, 104, 145-155. http://dx.doi.org/10.1016/j.cie.2016.11.028.

Boran, F. E., Genç, S., Kurt, M., \& Akay, D. (2009). A multi-criteria intuitionistic fuzzy group decision making for supplier selection with TOPSIS method. Expert Systems with Applications, 36(8), 11363-11368. http://dx.doi.org/10.1016/j.eswa.2009.03.039.

Chan, F. T. S., \& Kumar, N. (2007). Global supplier development considering risk factors using fuzzy extended AHP-based approach. Omega, 35(4), 417-431. http://dx.doi.org/10.1016/j.omega.2005.08.004.

Chang, S.-L., Wang, R.-C., \& Wang, S.-Y. (2006). Applying fuzzy linguistic quantifier to select supply chain partners at different phases of product life cycle. International Journal of Production Economics, 100(2), 348-359. http://dx.doi.org/10.1016/j.jpe.2005.01.002.

Chen, C. C. (2008). A model for customer-focused objective-based performance evaluation of logistics service providers. Asia Pacific Journal of Marketing and Logistics, 20(3), 309-322. http://dx.doi.org/10.1108/13555850810890075.

Chen, W., \& Zou, Y. (2017). An integrated method for supplier selection from the perspective of risk aversion. Applied Soft Computing, 54, 449-455. http://dx.doi.org/10.1016/j.asoc.2016.10.036.

Chen, Y. J. (2011). Structured methodology for supplier selection and evaluation in a supply chain. Information Sciences, 181(9), 16511670. http://dx.doi.org/10.1016/j.ins.2010.07.026.

Chen, Z., \& Yang, W. (2011). An MAGDM based on constrained FAHP and FTOPSIS and its application to supplier selection. Mathematical and Computer Modelling, 54(11-12), 2802-2815. http://dx.doi.org/10.1016/j.mcm.2011.06.068.

Corominas, A., Mateo, M., Ribas, 1., \& Rubio, S. (2015). Methodological elements of supply chain design. International Journal of Production Research, 53(16), 5017-5030. http://dx.doi.org/10.1080/00207543.2015.1013641.

De Boer, L., Labro, E., \& Morlacchi, P. (2001). A review of methods supporting supplier selection. European Journal of Purchasing \& Supply Management, \(2), 75-89. http://dx.doi.org/10.1016/S0969-7012(00)00028-9.

Dickson GW. (1966). An analysis of vendor selection systems and decisions. Journal of Purchasing, 2(1), 5-17. https://doi.org/10.1111/j.1745493X.1966.tb00818.x

Donato, V. (2008). Green Logistics: A socio-environmental approach (256 p.). Rio de Janeiro: Modern Science Ltda.

Dweiri, F., Kumar, S., Khan, S. A., \& Jain, V. (2016). Designing an integrated AHP based decision support system for supplier selection in automotive industry. Expert Systems with Applications, 62, 273-283. http://dx.doi.org/10.1016/j.eswa.2016.06.030. 
Ehrgott, M., Reimann, F., Kaufmann, L., \& Carter, C. R. (2011). Social sustainability in selecting emerging economy, suppliers. Journal of Business Ethics, 98(1), 99-119. http://dx.doi.org/10.1007/s10551-010-0537-7.

Elkington, J. (1998). Cannibals with forks: The triple bottom line of $21^{\text {st }}$ century business. Environmental Quality Management, 8(1), 37-51. http://dx.doi.org/10.1002/tqem.3310080106.

Erginel, N., \& Gecer, A. (2016). Fuzzy multi-objective decision model for calibration supplier selection problem. Computers \& Industrial Engineering, 102, 166-174. http://dx.doi.org/10.1016/j.cie.2016.10.017.

Fazlollahtabar, H., Mahdavi, I., Ashoori, M. T., Kaviani, S., \& Mahdavi-Amiri, N. (2011). A multi-objective decision-making process of supplier selection and order allocation for multi-period scheduling in an electronic market. International Journal of Advanced Manufacturing Technology, 52(9-12), 1039-1052. http://dx.doi.org/10.1007/s00170-010-2800-6.

Feng, B., Fan, Z.-P., \& Ma, J. (2010). A method for partner selection of codevelopment alliances using individual and collaborative utilities. International Journal of Production Economics, 124(1), 159-170. http://dx.doi.org/10.1016/j.jpe.2009.10.019.

Frej, E. A., \& Almeida, A. T. (2016, Setembro 27-30). Seleção de fornecedores em uma indústria de alimentos com base no método multricritério FITradeoff. In: Anais do XLVIII Brazilian Symposium on Operational Research, Vitória- ES. Rio de Janeiro: SOBRAPO.

Frej, E. A., De Almeida, A. T., \& Costa, A. P. C. S. (2019). Using data visualization for ranking alternatives with partial information and interactive tradeoff elicitation. Operations Research, 19, 1-22. http://dx.doi.org/10.1007/s12351-018-00444-2.

Gimenez, C., Sierra, V., \& Rodon, J. (2012). Sustainable operations: Their impact on the triple bottom line. International Journal of Production Economics, 140(1), 149-159. http://dx.doi.org/10.1016/j.jpe.2012.01.035.

Göl, H., \& Çatay, B. (2007). Third-party logistics provider selection: insights from a Turkish automotive company. Supply Chain Management, 12(6), 379-384. http://dx.doi.org/10.1108/13598540710826290.

Govindan, K., Rajendran, S., Sarkis, J., \& Murugesan, P. (2015). Multi criteria decision making approaches for green supplier evaluation and selection: a literature review. Journal of Cleaner Production, 98, 66-83. http://dx.doi.org/10.1016/j.jclepro.2013.06.046.

Gunasekaran, A., \& Spalanzani, A. (2011). Sustainability of manufacturing and services: Investigations for research and applications. International Journal of Production Economics, 140(1), 35-47. http://dx.doi.org/10.1016/j.jpe.2011.05.011.

Hamdan, S., \& Cheaitou, A. (2017). Supplier selection and order allocation with green criteria: An MCDM and multi-objective optimization approach. Computers \& Operations Research, 81, 282-304. http://dx.doi.org/10.1016/j.cor.2016.11.005.

Helleno, A. L., De Moraes, A. J. 1., \& Simon, A. T. (2017). Integrating sustainability indicators and Lean Manufacturing to assess manufacturing processes: application case studies in Brazilian industry. Journal of Cleaner Production, 153, 405-416. http://dx.doi.org/10.1016/j. jclepro.2016.12.072.

Ho, W., Xu, X., \& Dey, P. K. (2010). Multi-criteria decision making approaches for supplier evaluation and selection: A literature review. European Journal of Operational Research, 202(1), 16-24. http://dx.doi.org/10.1016/j.ejor.2009.05.009.

Jafari Songhori, M., Tavana, M., Azadeh, A., \& Khakbaz, M. H (2011). A supplier selection and order allocation model with multiple transportation alternatives. International Journal of Advanced Manufacturing Technology, 52(1-4), 365-376. http://dx.doi.org/10.1007/ s00170-010-2697-0.

Jolai, F., Yazdian, S. A., Shahanaghi, K., \& Khojastehet, M. A. (2011). Integrating fuzzy TOPSIS and multi- period goal programming for purchasing multiple products from multiple suppliers. Journal of Purchasing and Supply Management, 17(1), 42-53. http://dx.doi. org/10.1016/j.pursup.2010.06.004.

Kannan, D., Khodaverdi, R., Olfat, L., Jafarian, A., \& Diabat, A. (2013). Integrated fuzzy multi criteria decision making method and multiobjective programming approach for supplier selection and order allocation in a green supply chain. Journal of Cleaner Production, 47, 355-367. http://dx.doi.org/10.1016/j.jclepro.2013.02.010.

Keeney, R. L. (1996). Value-focused thinking: Identifying decision opportunities and creating alternatives. European Journal of Operational Research, 92(3), 537-549. http://dx.doi.org/10.1016/0377-2217(96)00004-5.

Keskin, G. A., llhan, S., \& Özkan, C. (2010). The fuzzy ART algorithm: A categorization method for supplier evaluation and selection. Expert Systems with Applications, 372), 1235-1240. http://dx.doi.org/10.1016/j.eswa.2009.06.004.

Khaleie, S., Fasanghari, M., \& Tavassoli, E. (2012). Supplier selection using a novel intuitionist fuzzy clustering approach. Applied Soft Computing, 12(6), 1741-1754. http://dx.doi.org/10.1016/j.asoc.2012.01.017.

Kilincci, O., \& Onal, S. A. (2011). Fuzzy AHP approach for supplier selection in a washing machine company. Expert Systems with Applications, 38(8), 9656-9664. http://dx.doi.org/10.1016/j.eswa.2011.01.159.

Lee, A. H. 1. (2009). A fuzzy supplier selection model with the consideration of benefits, opportunities, costs and risks. Expert Systems with Applications, 36(2), 2879-2893. http://dx.doi.org/10.1016/j.eswa.2008.01.045.

Lee, J., Cho, H., \& Kim, Y. S. (2015). Assessing business impacts of agility criterion and order allocation strategy in multi-criteria supplier selection. Expert Systems with Applications, 42(3), 1136-1148. http://dx.doi.org/10.1016/j.eswa.2014.08.041.

Levary, R. R. (2007). Ranking foreign suppliers based on supply risk. Supply Chain Management, 12(6), 392-394. http://dx.doi. org/10.1108/13598540710826317.

Liao, C.-N., \& Kao, H.-P. (2010). Supplier selection model using Taguchi loss function, analytical hierarchy process and multi-choice goal programming. Computers \& Industrial Engineering, 58(4), 571-577. http://dx.doi.org/10.1016/j.cie.2009.12.004.

Liao, C. N., \& Kao, H. P. (2011). An integrated fuzzy TOPSIS and MCGP approach to supplier selection in supply chain management. Expert Systems with Applications, 38(9), 10803-10811. http://dx.doi.org/10.1016/j.eswa.2011.02.031.

Liaoa, Z., \& Rittscher, J. (2007). A multi-objective supplier selection model under stochastic demand conditions. International Journal of Production Economics, 105(1), 150-159. http://dx.doi.org/10.1016/j.jpe.2006.03.001.

Lima Júnior, F. R., Osiro, L., \& Carpinetti, L. C. R. (2013). Multicriteria decision methods for supplier selection: a state of the art overview. Management \& Production, 20(4), 781-801. http://dx.doi.org/10.1590/S0104-530X2013005000005.

Lin, R., Chuang, C., Liou, J. J. H., \& Wu, G. (2009). An integrated method for finding key suppliers in SCM. Expert Systems with Applications, 36(3), 6461-6465. http://dx.doi.org/10.1016/j.eswa.2008.07.078.

Liu, F. H. F., \& Hai, H. L. (2005). The voting analytic hierarchy process method for selecting supplier. International Journal of Production Economics, 97(3), 308-317. http://dx.doi.org/10.1016/j.jpe.2004.09.005. 
Monczka, R. M., Handfield, R. B., Guinipero, L. C., \& Patterson, J. L. (2010). Purchasing and supply chain management. United Kingdom: Cengage learning.

Mota, B., Gomes, M. 1., Carvalho, A., \& Barbosa-Povoa, A. P. (2018). Sustainable supply chains: An integrated modeling approach under uncertainty. Elsevier. Omega, 77, 32-57. http://dx.doi.org/10.1016/j.omega.2017.05.006.

Ordoobadi, S. M. (2009). Development of a supplier selection model using fuzzy logic. Supply Chain Management, 14(4), 314-327. http:// dx.doi.org/10.1108/13598540910970144.

Ozkok, B. A., \& Tiryaki, F. (2011). A compensatory fuzzy approach to multi-objective linear supplier selection problem with multiple-item. Expert Systems with Applications, 38(9), 11363-11368. http://dx.doi.org/10.1016/j.eswa.2011.03.004.

Pagell, M., \& Gobeli, D. (2009). How plant managers' experiences and attitudes toward sustainability relate to operational performance. Production and Operations Management, 18(3), 278-299. http://dx.doi.org/10.1111/j.1937-5956.2009.01050.x.

Park, J., Shin, K., Chang, T.-W., \& Park, J. (2010). An integrative framework for supplier relationship management. Industrial Management \& Data Systems, 110(4), 495-515. http://dx.doi.org/10.1108/02635571011038990.

Punniyamoorthy, M., Mathiyalagan, P., \& Parthiban, P. (2011). A strategic model using structural equation modeling and fuzzy logic in supplier selection. Expert Systems with Applications, 38(1), 458-474. http://dx.doi.org/10.1016/j.eswa.2010.06.086.

Reuter, C., Foerstil, K., Hartmann, E., \& Blome, C. (2010). Sustainable global supplier management: The role of dynamic capabilities in achieving competitive advantage. The Journal of Supply Chain Management, 46(2), 45-63. http://dx.doi.org/10.1111/j.1745-493X.2010.03189.x.

Roy, B. (1996). Multicriteria methodology for decision aiding. Boston, MA. Springer US, 12. http://dx.doi.org/10.1007/978-1-4757-2500-1.

Sanayei, A., Mousavi, S. F., \& Yazdankhah, A. (2010). Group decision making process for supplier selection with VIKOR under fuzzy environment. Expert Systems with Applications, 371), 24-30. http://dx.doi.org/10.1016/j.eswa.2009.04.063.

Sarkara, A., \& Mohapatra, P. K. J. (2006). Evaluation of supplier capability and performance: A method for supply base reduction. Journal of Purchasing and Supply Management, 12(3), 148-163. http://dx.doi.org/10.1016/j.pursup.2006.08.003.

Sarkis, J., \& Talluri, S. (2002). A model for strategic supplier selection. The Journal of Supply Chain Management, 38(1), 18-28. http:// dx.doi.org/10.1111/j.1745-493X.2002.tb00117.x.

Schütz, P., Tomasgard, A., \& Ahmed, S. (2009). Supply chain design under uncertainty using sample average approximation and dual decomposition. European Journal of Operational Research, 199(2), 409-419. http://dx.doi.org/10.1016/j.ejor.2008.11.040.

Segura, M., \& Maroto, C. (2017). A multiple criteria supplier segmentation using outranking and value function methods. Expert Systems with Applications, 69, 87-100. http://dx.doi.org/10.1016/j.eswa.2016.10.031.

Shemshadi, A., Shirazi, H., Toreihi, M., \& Tarokh, M. J. (2011). Fuzzy VIKOR method for supplier selection based on entropy measure for objective weighting. Expert Systems with Applications, 38(10), 12160-12167. http://dx.doi.org/10.1016/j.eswa.2011.03.027.

Shen, C., \& Yu, K. (2009). Enhancing the efficacy of supplier selection decision-making on the initial stage of new product development: A hybrid fuzzy approach considering the strategic and operational factors simultaneously. Expert Systems with Applications, 36(8), 11271-11281. http://dx.doi.org/10.1016/j.eswa.2009.02.083.

Shi, L., Wu, K. J., \& Tseng, M. L. (2017). Improving corporate sustainable development: using an interdependence hierarchical model. Resources, Conservation and Recycling, 119, 24-35. http://dx.doi.org/10.1016/j.resconrec.2016.08.014.

Slaper, T., \& Hall, T. (2011). The triple bottom Line: what is it and how does it work? Indiana Business Review, 86(1), 4-8.

Su, C. M., Horng, D. J., Tseng, M. L., Chiu, A. S., Wu, K. J., \& Chen, H. P. (2016). Improving sustainable supply chain management using a novel hierarchical grey-DEMATEL approach. Journal of Cleaner Production, 134, 469-481. http://dx.doi.org/10.1016/j.jclepro.2015.05.080.

Ting, S., \& Cho, D. (2008). An integrated approach for supplier selection and purchasing decisions. Supply Chain Management, 13(2), 116-127. http://dx.doi.org/10.1108/13598540810860958.

Universidade Federal de Pernambuco. Centro de Desenvolvimento em Sistemas de Informação e Decisão. (2019). Flexible and Interactive Tradeoff - FITradeoff DSS. Recife: CDSID. Retrieved in 2019 October 10, from www.fitradeoff.org

Wan, S. P., Xu, G. L., Wang, F., \& Dong, J. Y. (2015). A new method for Atanassov's interval-valued intuitionistic fuzzy MAGDM with incomplete attribute weight information. Information Sciences, 316, 329-347. http://dx.doi.org/10.1016/j.ins.2015.04.019.

Wan, S. P., Wang, F., \& Dong, J. Y. (2016). A preference degree for intuitionistic fuzzy values and application to multi-attribute group decision making. Information Sciences, 370-371, 127-146. http://dx.doi.org/10.1016/j.ins.2016.07.013.

Wan, S., Xu, G., Dong, J. (2017). Supplier selection using ANP and ELECTRE 11 in interval 2-tuple linguistic environment. Information Sciences, 385-386, 19-38. https://doi.org/10.1016/j.ins.2016.12.032

Wu, C., \& Barnes, D. (2011). A literature review of decision-making models and approaches for partner selection in agile supply chains. Journal of Purchasing and Supply Management, 174), 256-274. http://dx.doi.org/10.1016/j.pursup.2011.09.002.

Xia, W., \& Wu, Z. (2007). Supplier selection with multiple criteria in volume discount environments. Journal of Management Science, 35, 494-504.

Yang, J. L., \& Tzeng, G. H. (2011). An integrated MCDM technique combined with DEMATEL for a novel cluster-weighted with ANP method. Expert Systems with Applications, 38(3), 1417-1424. http://dx.doi.org/10.1016/j.eswa.2010.07.048.

Yayla, A. Y., Yildiz, A., \& Ozbek, A. (2012). Fuzzy TOPSIS method in supplier selection and application in the garment industry. Fibres \& Textiles in Eastern Europe, 20(4), 20-23.

Yeh, W. C., \& Chuang, M. C. (2011). Using multi-objective genetic algorithm for partner selection in green supply chain problems. Expert Systems with Applications, 38(4), 4244-4425. http://dx.doi.org/10.1016/j.eswa.2010.09.091.

Zeydan, M., Çolpan, C., \& Çobanoglu, C. (2011). A combined methodology for sup- plier selection and performance evaluation. Expert Systems with Applications, 38(3), 2741-2751. http://dx.doi.org/10.1016/j.eswa.2010.08.064.

Zhang, D., Zhang, J., Lai, K.-K., \& Lu, Y. (2009). An novel approach to supplier selection based on vague sets group decision. Expert Systems with Applications, 36(5), 9557-9563. http://dx.doi.org/10.1016/j.eswa.2008.07.053. 